Annales Missiologici Posnanienses t. 24 (2019), s. 101-118

doi: $10.14746 / \mathrm{amp} .2019 .24 .7$

ORCID: 0000-0002-1158-5644

MAGDALENA RZYM

Uniwersytet Kardynała Stefana Wyszyńskiego w Warszawie

Wydział Teologiczny

\title{
Dialog czy misja? Dokumenty misyjne Kościoła wobec dialogu międzyreligijnego
}

W przeszłości katolicka ocena religii niechrześcijańskich sprowadzała się do wniosku, że są one wynikiem błędów ludzkich, a nawet działania Szatana, utrzymują człowieka w ciemności fałszywej wiary i prowadzą do zguby wiecznej. W wielu wypowiedziach papieży i soborów zawierało się także przekonanie, że do zbawienia niezbędna jest nie tylko wiara w Jezusa Chrystusa, ale również przynależność do Kościoła katolickiego. „Nikt żyjący poza Kościołem katolickim, nie tylko poganie, lecz także Żydzi, heretycy i schizmatycy, nie mogą stać się uczestnikami życia wiecznego, lecz pójdą w ogień wieczny [...], jeżeli przed końcem życia nie przyłączą się do Kościoła" ogłosił sobór we Florencji w 1442 r. (Sobór we Florencji 49). Zwyciężyło jednak przekonanie, że ci, którzy w sposób niezawiniony nie znają Kościoła, ale zachowują prawo naturalne i wiodą uczciwe życie, mogą osiągnąć zbawienie na mocy łaski Bożej (Pius IX 124-125).

Przed Soborem Watykańskim II Kościół nie podejmował głębszej refleksji nad religiami pozachrześcijańskimi. Był to temat w zasadzie nieobecny w wypowiedziach Urzędu Nauczycielskiego Kościoła. Wyjątek stanowiły dokumenty o charakterze misyjnym, w których wzmianki o innych religiach pojawiały się w kontekście misji ad gentes. Religie niechrześcijańskie były tam określane jako systemy błędne, utrzymujące w cieniu śmierci, natomiast sens działalności misyjnej przedstawiano jako wyrywanie z ciemności i zabobonów fałszywej wiary. W tym duchu snuł refleksję Grzegorz XVI w encyklice Probe nostis, ukazując pracę misjonarzy jako tych, którzy toczą „boje Pańskie” przeciw herezjom i niewierze, pozyskują ,siedzących w ciemnościach i w cieniu śmierci, aby przyprowadzić ich do światła i życia wiary katolickiej. [...] przez chrzest odrodzenia wyrywają ich $\mathrm{z}$ niewoli szatana i włączają w sze- 
regi wolnych, przybranych dzieci Bożych" (Grzegorz XVI 123). Leon XIII w encyklice Sancta Dei Civitas twierdził, że adresaci misji są wyprowadzani „ze skazy błędów i ciemności śmierci”, „przechodzą od nieokrzesanego sposobu życia i dzikich obyczajów do wszelkiej kultury" (Leon XIII, Sancta Dei 140). Ten sam papież w encyklice Catholicae Ecclesiae uznawał za konieczne krzewienie „na terenach Afryki nauki Ewangelii, aby jej mieszkańcy siedzący w mrokach ślepego zabobonu, oświeceni przez nią światłem Bożej prawdy, stali się razem z nami uczestnikami dziedzictwa Królestwa Bożego" (Leon XIII, Catholicae Ecclesiae 143). Benedykt XV w liście apostolskim Maximum illud (1919) wezwał misjonarzy do „niesienia światłości tym, co pogrążeni są w mrokach śmierci [...], otwierania drogi do nieba tym, co idą ku zatraceniu". Zwracał się też z pytaniem: „Która część ludzi bardziej potrzebuje braterskiej pomocy niż poganie, którzy nie znając Boga, skrępowani ślepymi i wyuzdanymi pożądliwościami, pogrążeni są w najgorszej ze wszystkich - niewoli szatańskiej?" (Benedykt XV 161).

Perspektywa Kościoła zmieniła się wraz z Soborem Watykańskim II. Refleksja objęła religie niechrześcijańskie, w których dostrzeżono wiele prawd i wartości bliskich objawieniu chrześcijańskiemu. Sobór, nawiązując do starożytnego nauczania ojców Kościoła, uznał, iż stanowią one „drogę wychowawczą ku prawdziwemu Bogu” (paedagogia) i ,przygotowanie ewangeliczne” (preparatio evangelica), wskazał obecne w nich „nasiona Słowa” (semina Verbi) i stwierdził, że „Kościół katolicki nic nie odrzuca z tego, co w religiach owych prawdziwe jest i święte" (DRN 2). Nowym modelem ustosunkowania się Kościoła do religii niechrześcijańskich stał się dialog międzyreligijny. Dokumentem kluczowym dla dialogu jest soborowa deklaracja Nostra aetate - o stosunku Kościoła do religii niechrześcijańskich, ogłoszona 28 października 1965 r. Ten pierwszy w historii dokument, poświęcony w całości religiom innym niż chrześcijaństwo, wskazuje na pozytywne i zbawcze elementy, które obecne są w judaizmie, islamie, buddyzmie i hinduizmie. Jak zauważa Eugeniusz Sakowicz,

Kościół po raz pierwszy w dziejach wypowiedział się 'urzędowo' na temat elementów doktryny różnych religii, które zauważone i docenione zostały przez pasterzy i wiernych Kościoła. Ojcowie soboru wyjaśnili sens, znaczenie i potrzebę dialogu. Zwrócili uwagę na korelację między misjami a dialogiem. Dialog przedstawiony został jako integralna część przepowiadania realizowana w ramach powszechnej misji Kościoła (Sakowicz, Dialog międzyreligijny 132).

Poza deklaracją Nostra aetate wzmianki o innych religiach pojawiają się także w takich tekstach soborowych jak: Konstytucja dogmatyczna o Kościele Lumen gentium, Konstytucja duszpasterska o Kościele Gaudium et spes, De- 
kret o działalności misyjnej Kościoła Ad gentes divinitus i Deklaracja o wolności religijnej Dignitatis humanae.

Przyjęcie przez Kościół idei dialogu międzyreligijnego nie oznacza bynajmniej rezygnacji z działalności misyjnej. Zarówno dokumenty soborowe, jak i późniejsze teksty oraz wypowiedzi Magisterium Ecclesiae rozwiewają te wątpliwości i kładą nacisk na aktualność wezwania misyjnego Jezusa Chrystusa. Jednocześnie, odchodząc od dawnego języka polemiki i konfrontacji, wskazują na ścisły związek zachodzący między dialogiem z religiami niechrześcijańskimi a głoszeniem Ewangelii ich wyznawcom. Znaczącym faktem jest, że temat dialogu międzyreligijnego podejmowany jest najczęściej w dokumentach o charakterze misyjnym.

Sobór Watykański II oraz dokumenty dykasterii watykańskich ${ }^{1}$ i papieży: Pawła VI, Jana Pawła II, Benedykta XVI i Franciszka, wskazują, że działalność misyjna obejmuje także - obok głoszenia Ewangelii w ścisłym sensie - dialog międzyreligijny. Dialog ten stanowi jedną z dróg misji, ale ich nie wyczerpuje (Kluj, Misje 347). Niniejszy artykuł podejmuje temat korelacji między tymi dwiema formami działalności Kościoła. Jego celem jest ukazanie, jak współczesne, misyjne dokumenty Kościoła postrzegają religie niechrześcijańskie oraz sens i znaczenie dialogu międzyreligijnego.

\section{Nowa perspektywa dialogu}

Dekret o działalności misyjnej Kościoła Ad gentes divinitus został zatwierdzony w ostatnim dniu roboczym Soboru, czyli 7 grudnia 1965 r., choć prace nad nim trwały od $1960 \mathrm{r}^{2}$ Jest to jeden z pierwszych dokumentów Kościoła, w którym pojawia się pozytywny obraz religii niechrześcijańskich. Dekret wskazuje na pozytywne elementy obecne w religiach i kulturach, nazywając je „dobrym posiewem”, „drogą wychowawczą” i ,przygotowaniem ewangelicznym” (DM 3,9) ${ }^{3}$. Dokument ten zwraca uwagę, że poprzez ,przedsięwzięcia natury religijnej, w których ludzie na różny sposób szukają Boga”, dokonuje się powszechny Boży plan zbawienia. Stwierdza, że owe „przedsięwzięcia

${ }^{1}$ Zagadnienia dialogu międzyreligijnego rozwinięte zostały w następujących dokumentach Sekretariatu dla Niechrześcijan: Sugestie do dialogu między religiami (1967) i Postawa Kościoła wobec wyznawców innych religii (1984) oraz Międzynarodowej Komisji Teologicznej: Chrześcijaństwo i religie (1997). Wartym uwagi komentarzem do ostatniego dokumentu jest opracowanie Łukasza Kamykowskiego (Kamykowski 101-122).

${ }^{2}$ Pod koniec 1960 r. wyznaczono skład Misyjnej Komisji Przygotowawczej, która rozpoczęła prace nad tekstem dekretu. Genezę dokumentu dokładnie przedstawia w swoim opracowaniu Joseph Masson (Masson 11-25).

${ }^{3}$ Pojęcia te mają źródło w tekstach patrystycznych. 
potrzebują oświecenia i uleczenia, chociaż za łaskawym wyrokiem dobrotliwego Boga można je niekiedy uważać za drogę wychowawczą (paedagogia) ku prawdziwemu Bogu lub za przygotowanie ewangeliczne" (DM 3). W ten sposób dokument uznaje dostępność zbawienia dla ludzi, którzy nie poznali Ewangelii, nie zwalnia to wszakże Kościoła z zadania głoszenia Dobrej Nowiny. Bóg, sobie tylko wiadomymi drogami, może doprowadzić każdego człowieka do wiary i zbawienia, ,jednak na Kościele ciąży konieczność i równocześnie święte prawo głoszenia Ewangelii, a wobec tego działalność misyjna tak dziś, jak i zawsze zachowuje w pełni swą moc i konieczność" (DM 7). Wartości obecne w religiach niechrześcijańskich oczekują na spotkanie z Ewangelią, która nie niweczy ich, ale je udoskonala:

jakikolwiek dobry posiew znajdujący się w sercach i umysłach ludzkich lub we własnych obrządkach i kulturach narodów, nie tylko nie ginie, lecz doznaje uleczenia, wyniesienia na wyższy poziom i pełnego udoskonalenia na chwałę Bożą, na zawstydzenie szatana i dla szczęścia człowieka (DM 9).

Pojęcie dialogu międzyreligijnego podejmuje i rozwija w swoim nauczaniu papież Paweł VI. Jego encyklika Ecclesiam suam (z 6 sierpnia 1964) nazwana została „wielką kartą dialogu” (Sakowicz, Dialog międzyreligijny 136), ponieważ papież określa w niej cechy i motywy dialogu oraz wyróżnia jego kręgi (Paweł VI, Ecclesiam suam 106-107). Paweł VI rozpatruje dialog międzyreligijny w kontekście działalności misyjnej Kościoła. Zwracając się do członków Papieskich Dzieł Misyjnych, zachęca do odkrywania wartości duchowych i ludzkich w innych religiach oraz dostrzeżenia w nich „tajemniczej predyspozycji do pełnego światła Objawienia" (Paweł VI, Przemówienie... 242). Wskazuje na potrzebę uznania, że Bóg ma także inne drogi zbawienia dusz, nie zwalnia to jednak chrześcijan z obowiązku głoszenia wszystkim Ewangelii (Paweł VI, Przemówienie... 242). Te same tematy rozwinięte zostały w adhortacji Evangelii nuntiandi (z 8 grudnia 1975), uważanej za najważniejszy - obok soborowego dekretu Ad gentes divinitus i encykliki Jana Pawła II Redemptoris missio - dokument poświęcony problematyce misyjnej. Kontekst, w jakim powstała adhortacja, to dziesiąta rocznica zakończenia Soboru Watykańskiego II $^{4}$ oraz trzecie ogólne zebranie Synodu Biskupów, który rozpatrywał problem ewangelizacji ${ }^{5}$. Papież definitywnie wskazuje na nieodzowność głoszenia Ewangelii, które ,jest zgoła konieczne, jest jedyne

\footnotetext{
${ }^{4}$ Paweł VI tak określa postulaty Soboru Watykańskiego II: „,dokładać starań, żeby Kościół XX wieku stał się bardziej zdatny do głoszenia Ewangelii ludziom tegoż stulecia” (Paweł VI, Evangelii nuntiandi 3).

${ }^{5}$ Synod odbywał się w dniach od 27 września do 26 października 1974 r., a tematem obrad była Ewangelizacja w świecie wspótczesnym.
} 
w swoim rodzaju i nic go nie może zastąpić" (Paweł VI, Evangelii nuntiandi 5). Rozpatruje łącznie problematykę misji i temat religii niechrześcijańskich. Deklaruje szacunek dla innych religii, nazywa je ,wyrazem ducha bardzo wielu grup ludzkich” i dostrzega w nich „echo głosów tych, którzy przez tysiące lat szukali Boga" (w sposób niedoskonały, ale szczerze i należycie), z uznaniem odnosi się także do ich religijnych tekstów, które nauczyły wiele pokoleń ludzi modlitwy, zawierają niezliczone „nasiona Słowa” i są ,przygotowaniem do Ewangelii" (Paweł VI, Evangelii nuntiandi 53). Przypomina jednak, że ,ani wielki szacunek dla tych religii, ani złożoność podnoszonych problemów nie skłaniają Kościoła do zamilczenia przed niechrześcijanami orędzia Jezusa Chrystusa" (Paweł VI, Evangelii nuntiandi 53).

\section{Jan Paweł II: dialog i inkulturacja}

Jan Paweł II w jeszcze większym stopniu niż Paweł VI uwypukla znaczenie dialogu międzyreligijnego i określa go jako integralną część posłannictwa Kościoła (Kluj, Teologiczne podstawy... 187). Pontyfikat papieża Polaka pełen jest znaczących i przełomowych wydarzeń w relacjach Kościoła katolickiego z innymi tradycjami religijnymi. Świadczą o tym m.in.: pierwsza w historii wizyta głowy Kościoła w synagodze (Rzym, 13 kwietnia 1986) i meczecie (Damaszek, 6 maja 2001), Światowy Dzień Modlitwy o Pokój w Asyżu (27 października 1986 i 26 stycznia 2002) oraz liczne spotkania z przywódcami i wiernymi religii niechrześcijańskich (wśród nich na szczególną uwagę zasługują: spotkanie z młodzieżą muzułmańską w Casablance 19 sierpnia 1985 oraz podróż apostolska do Jordanii i Izraela 20-26 marca 2000) $)^{6}$. Jan Paweł II wskazuje jednocześnie na konieczność działalności misyjnej i podkreśla, że każdy człowiek „ma prawo usłyszeć Dobrą Nowinę Boga, który objawia się i daje siebie w Chrystusie" (Jan Paweł II, Redemptoris missio 46).

Problematyka dialogu międzyreligijnego, rozpatrywanego w kontekście misji chrześcijańskich, podjęta jest w encyklice Redemptoris missio. Dokument opublikowany został 7 grudnia 1990 r., w 25. rocznicę ogłoszenia dekretu Ad gentes divinitus. Papież zwraca w nim uwagę na współczesne zagrożenie, jakim jest redukowanie znaczenia Jezusa Chrystusa i Kościoła oraz sprowadzanie działalności misyjnej do pomocy ubogim i zaangażowania na

\footnotetext{
${ }^{6}$ Wypowiedzi Jana Pawła II na temat religii niechrześcijańskich zebrano w następujących pozycjach książkowych: Islam w dokumentach Kościoła i nauczaniu Jana Pawła II (1965-1996). Red. Eugeniusz Sakowicz. Warszawa: Wydawnictwo UKSW, 1997; Żydzi i judaizm w nauczaniu Jana Pawła II (1978-2005). Red. Waldemar Chrostowski. Warszawa: Wydawnictwo Archidiecezji Warszawskiej, 2005; Nauczycielski Urząd Kościoła a religie. Red. Ireneusz Ledwoń. Lublin: Wydawnictwo KUL, 2015. 271-586.
} 
rzecz polepszenia sytuacji społeczno-ekonomicznej. Przypomina o stałej aktualności powołania misyjnego ${ }^{7}$, wskazując, że postawa misyjna należy do samej natury Kościoła. Jednocześnie z całym przekonaniem stwierdza, że głoszenie absolutnego charakteru Prawdy objawionej nie wyklucza dialogu między wyznaniami chrześcijańskimi i innymi religiami (Zięba XVI-XVII). W piątym rozdziale encykliki Redemptoris missio, poświęconym formom działalności misyjnej Kościoła, dialog międzyreligijny wymieniony zostaje jako jedna $\mathrm{z}$ nich.

Papież podkreśla, że dialog międzyreligijny należy do misji ewangelizacyjnej Kościoła, nie przeciwstawia się misji ad gentes, ale jest z nią powiązany i stanowi jej wyraz:

Bóg powołuje do siebie w Chrystusie wszystkie narody, pragnąc im przekazać pełnię swego Objawienia i swej miłości; czyni wszystko, aby na różne sposoby być obecnym nie tylko dla poszczególnych jednostek, ale także dla narodów poprzez ich bogactwa duchowe, których głównym i zasadniczym wyrazem są religie, chociaż mają one braki, niedostatki i błędy (Jan Paweł II, Redemptoris missio $55)$.

Kościół nie widzi sprzeczności między głoszeniem Jezusa Chrystusa a dialogiem międzyreligijnym i pragnie, aby „oba te elementy zachowywały swą ścisłą więź i zarazem swą odrębność" (Jan Paweł II, Redemptoris missio 55).

Jan Paweł II w encyklice Redemptoris missio podejmuje refleksję nad dostępnością zbawienia poza widzialnymi granicami Kościoła. „Powszechność zbawienia nie oznacza, że otrzymują je tylko ci, którzy w wyraźny sposób wierzą w Chrystusa i weszli do Kościoła" - stwierdza w dokumencie. Zbawienie zostało przeznaczone dla całej ludzkości, dlatego musi być ono dane do dyspozycji wszystkim ludziom. Wielu z nich nie ma możliwości poznania czy przyjęcia Ewangelii i wejścia do Kościoła: dzieje się tak ze względu na warunki społeczno-kulturowe, w których żyją, oraz ze względu na wychowanie w innych tradycjach religijnych. Papież pisze:

Dla nich Chrystusowe zbawienie dostępne jest mocą łaski, która, choć ma tajemniczy związek z Kościołem, nie wprowadza ich do niego formalnie, ale oświeca ich w sposób odpowiedni do ich sytuacji wewnętrznej i środowiskowej. Łaska ta pochodzi od Chrystusa, jest owocem Jego ofiary i zostaje udzielana przez Ducha Świętego (Jan Paweł II, Redemptoris missio 10).

Dialog z wyznawcami religii niechrześcijańskich jest także jednym z tematów poruszanych przez Jana Pawła II w adhortacjach: Ecclesia in Africa,

\footnotetext{
${ }^{7}$ Podtytuł encykliki: O stałej aktualności posłania misyjnego.
} 
Ecclesia in America, Ecclesia in Asia i Ecclesia in Oceania. Dokumenty te, opublikowane kolejno w latach 1995-2001, uwzględniają wkład synodów biskupów, które obradowały podczas zwołanych w Rzymie specjalnych zgromadzeń. Papież, zwracając się do Kościołów na poszczególnych kontynentach, wskazuje na stojące przed nimi wyzwania, również te związane z relacjami z religiami niechrześcijańskimi.

Posynodalna adhortacja Ecclesia in Africa jest owocem refleksji, dyskusji i wymiany doświadczeń - poświęconego Afryce - Specjalnego Zgromadzenia Synodu Biskupów, które miało miejsce w Watykanie od 10 kwietnia do 8 maja 1994 r. Tematem zgromadzenia stał się: „Kościół w Afryce i jego misja ewangelizacyjna u progu roku 2000: 'Będziecie moimi świadkami' (Dz 1,8)”. Adhortacja, podpisana po upływie roku w Jaunde w Kamerunie, odnosi się do specyfiki, potrzeb, wyzwań i celów działania Kościoła w Afryce, podkreślając jego misyjny charakter.

Wyzwaniem stojącym przed Kościołem afrykańskim jest, według Jana Pawła II, m.in. dialog międzyreligijny. Widać to już we wstępie, w którym papież zwraca się „,do Pasterzy oraz do wiernych świeckich, a następnie do braci innych wyznań chrześcijańskich, do wszystkich wyznawców wielkich religii monoteistycznych, zwłaszcza tradycyjnej religii afrykańskiej” (Jan Paweł II, Ecclesia in Africa 7). W rozdziale trzecim, poświęconym ewangelizacji i inkulturacji, wymienione zostają następujące płaszczyzny dialogu: własna wspólnota, inne wyznania chrześcijańskie oraz wszyscy ludzie dobrej woli. Papież wskazuje w pierwszej kolejności na wyznawców islamu, którzy, podobnie jak chrześcijanie, naśladują wiarę Abrahama i uznają wynikające z Dekalogu zasady moralne. Jan Paweł II apeluje zarówno do muzułmanów, jak i do chrześcijan, o respektowanie wolności religijnej i o wspólny sprzeciw wobec zjawisk takich jak fundamentalizm czy nielojalność w życiu politycznym i społecznym ${ }^{8}$. Odnosi się następnie do tradycyjnych religii afrykańskich i zwraca uwagę na ich „pozytywne wartości, takie jak wiara w Istotę Najwyższą i Wieczną, Stwórcę, Dawcę i sprawiedliwego Sędziego, które dobrze współbrzmią z prawdami wiary”. Na tej podstawie stwierdza: „Można w nich wręcz dostrzec 'przygotowanie na przyjęcie Ewangelii', zawierają one bowiem cenne semina Verbi, które mogą doprowadzić wielką liczbę ludzi - jak

8 „Chrześcijanie nie mogą zapominać, że wielu muzułmanów stara się naśladować wiarę Abrahama i żyć zgodnie z nakazami Dekalogu. [...] Należy więc szczególnie dbać o to, aby obydwie strony dialogu islamsko-chrześcijańskiego respektowały zasadę wolności religijnej z wszystkimi jej konsekwencjami, takimi jak zewnętrzne i publiczne wyrażanie wiary. Chrześcijanie i muzułmanie są powołani, aby prowadzić dialog, unikając zagrożeń, jakie rodzą się z fałszywego irenizmu albo z wojowniczego fundamentalizmu, oraz aby sprzeciwiać się głośno nielojalności w polityce i w działaniu, a także wszelkiemu brakowi wzajemności w dziedzinie wolności religijnej" (Jan Paweł II, Ecclesia in Africa 66). 
działo się już w przeszłości - do 'otwarcia się na pełnię Objawienia w Jezusie Chrystusie" (Jan Paweł II, Ecclesia in Africa 66). Jan Paweł II akcentuje pozytywne aspekty tradycyjnych religii afrykańskich, które mogą być wspólną płaszczyzną dialogu, pomocną przy głoszeniu przez Kościół prawdy o Jezusie Chrystusie. Istotną zatem rolę odgrywa dla ewangelizacji tego kontynentu inkulturacja, ponieważ bogactwem Kościoła Afryki jest jego własna kultura. Wierni włączani są do Kościoła wraz ze swoją kulturą i jej wartościami. Choć pewne elementy trudne są do pogodzenia z Ewangelią, tradycja afrykańska może również pomagać w lepszym rozumieniu misji Jezusa Chrystusa (Piotrowski, Prawdziwy Kościół... 125). Wskutek zetknięcia się Ewangelii z lokalnymi pojęciami i wyobrażeniami wykształciły się obrazy Jezusa Chrystusa jako Przodka, Władcy, Lekarza i Uzdrowiciela (Szuppe 149-157).

Adhortacja Jana Pawła II Ecclesia in America ${ }^{9}$ skierowana jest do obu Ameryk i stanowi zwieńczenie Specjalnego Synodu Biskupów dla Ameryki, który odbył się w 1997 r. w Rzymie. Opublikowana została w styczniu 1999 r. podczas pielgrzymki do Meksyku. W rozdziale czwartym, zatytułowanym „Droga do komunii”, omówione są relacje z chrześcijanami innych wyznań i z innymi religiami, szczególnie z judaizmem. Wynika to z faktu, że w Ameryce istotną dla Kościoła rolę odgrywa dialog ze wspólnotami żydowskimi, licznymi w tamtejszym społeczeństwie. Zwracając na ten fakt uwagę, papież przypomina o wyjątkowej relacji chrześcijan z ludem żydowskim: „Z tego narodu narodził się Jezus, który dał początek swojemu Kościołowi w łonie Narodu żydowskiego. Większa część Pisma Świętego, którą my chrześcijanie czytamy jako Słowo Boże, stanowi wspólne dziedzictwo z Żydami” (Jan Paweł II, Ecclesia in America 50). Następnie Kościół Ameryki zostaje wezwany do okazywania szacunku i utrzymywania dobrych relacji z religiami autochtonicznymi. Papież przypomina za deklaracją Nostra aetate, że „,jeśli chodzi o religie niechrześcijańskie, Kościół katolicki nie odrzuca niczego, co jest w nich prawdziwe i święte”. Dlatego katolicy powinni zauważać „elementy prawdy” obecne w innych religiach i jednocześnie „dawać zdecydowane świadectwo nowości objawienia Chrystusowego, integralnie zachowywanego przez Kościół”. Dlatego Kościół odrzuca wszelką dyskryminację i prześladowanie z powodu rasy, koloru skóry, sposobu życia lub innej religii; ,przeciwnie, osoby wyznające odmienne religie powinny czuć się zobowiązane, właśnie z motywów religijnych, do współpracy na rzecz pokoju i sprawiedliwości” (Jan Paweł II, Ecclesia in America 51).

$\mathrm{Na}$ wartości obecne w religiach tradycyjnych wskazuje też papież, kiedy zwraca się do Kościoła Oceanii w adhortacji Ecclesia in Oceania. W 1998 r.

\footnotetext{
${ }^{9}$ Podtytuł dokumentu: O spotkaniu z żyjącym Jezusem Chrystusem, droga do komunii i solidarności w Ameryce.
} 
w Rzymie obradowało Specjalne Zgromadzenie Synodu Biskupów dla Oceanii. Posynodalna adhortacja opublikowana została trzy lata później - w 2001 r.; jej podtytuł brzmi: O Jezusie Chrystusie i ludach Oceanii: Iść Jego droga, głosić Jego prawdę, żyć Jego życiem.

Jan Paweł II z uznaniem pisze o religiach ludów Oceanii, „,które od niepamiętnych już czasów posiadały głęboki zmysł sacrum. Praktyki i obrzędy religijne stanowiły integralną część ich codziennego życia i głęboko przenikały ich kultury" (Jan Paweł II, Ecclesia in Oceania 7). Papież zwraca w ten sposób uwagę na pozytywne aspekty występujące w różnych sferach tradycyjnych religii Oceanii. Wartością sfery religijnej jest głębokie przeżywanie tajemnicy Boga, czczonego jako Istota Najwyższa, wyposażonego w szereg przymiotów bliskich chrześcijańskiej wizji Boga. Ważne dla ludów Oceanii jest również przeświadczenie o przenikaniu sacrum do codziennego życia. Sfera rytualna wyraża się w licznych obrzędach uświęcających doroczne wydarzenia i kolejne momenty życia. Sfery - kulturowa i społeczna - wyróżniają się zaangażowaniem całej wspólnoty w wychowanie dzieci i przekazywanie im wartości, szacunkiem do starszych, poczuciem przynależności plemiennej i troską o rodzinę. Ważną przestrzenią dialogu jest także sfera moralna, ponieważ tradycyjny kodeks moralny mieszkańców Oceanii w wielu aspektach bliski jest zasadom wyznawanym przez chrześcijan. Dotyczy to zwłaszcza poszanowania życia i wartości rodzinnych (Sakowicz, Dialog Kościoła... 118-121).

Inkulturacja i dialog międzyreligijny stanowią ważny aspekt działalności Kościoła na każdym z kontynentów, a wyjątkowe znaczenie zyskują w kontekście Kościoła Azji. Kontynent ten ma najniższy odsetek chrześcijan, jednak współcześnie zaobserwować można prężny rozwój Kościoła. W 1998 r. w Rzymie miało miejsce Specjalne Zgromadzenie Synodu Biskupów Azji. Synod ten poprzedzono długimi przygotowaniami, a jego tematem był: „Jezus Chrystus, Zbawiciel i Jego misja miłości i służby w Azji: 'Aby mieli życie i mieli je w obfitości’ (J 10,10)" (Piotrowski, Historia powstania... 100). Wydarzenie zaowocowało posynodalną adhortacją Ecclesia in Asia, podpisaną przez Jana Pawła II w 1999 r. w New Delhi. W rozdziale czwartym dokumentu, poświęconym inkulturacji, ewangelizacji i dialogowi międzyreligijnemu, papież przypomina, że Azja jest kolebką największych religii świata - judaizmu, chrześcijaństwa, islamu i hinduizmu, a także wielu innych duchowych tradycji, takich jak: buddyzm, taoizm, konfucjanizm, parsyzm, zaratusztrianizm, dżinizm, sikhizm i szintoizm. „Kościół żywi głęboki szacunek do tych tradycji” - deklaruje papież - ,i próbuje nawiązać szczery dialog z ich zwolennikami. Zawarte w nich wartości religijne oczekują swego dopełnienia w Jezusie Chrystusie" (Jan Paweł II, Ecclesia in Asia 6).

Jan Paweł II docenia wartości religijne i kulturowe religii azjatyckich. Pisze: 
Ludy Azji są dumne ze swych wartości religijnych i kulturowych - takich jak umiłowanie ciszy i kontemplacji, prostota, harmonia, oderwanie od świata, łagodność, zamiłowanie do ciężkiej pracy, dyscyplina, umiarkowanie, głód wiedzy i poznania filozoficznego. Przywiązane są do takich wartości, jak: szacunek dla życia, współczucie dla wszystkich istot żyjących, obcowanie z przyrodą, synowskie uczucia wobec rodziców, starszych i wszystkich przodków; mają też wysoko rozwinięty zmysł wspólnotowy (Jan Paweł II, Ecclesia in Asia 6).

Te wszystkie religijne wartości Azji oczekują na dopełnienie poprzez przyjęcie Jezusa Chrystusa. Aby było to możliwe, należy w głoszeniu Ewangelii ukazywać taki Jego obraz, który jest „zrozumiały dla mentalności i kultur azjatyckich, a jednocześnie wierny Pismu Świętemu i Tradycji” (Jan Paweł II, Ecclesia in Asia 20). Chrześcijanie, chcąc przybliżyć Jezusa Chrystusa wyznawcom innych religii, muszą Go zatem przedstawiać jako Kogoś zawsze im bliskiego i już obecnego - choć w ukryty sposób - w ich religijnych tradycjach. Dlatego papież, za ojcami synodalnymi, proponuje misjonarzom następujące obrazy Jezusa Chrystusa: „Mistrz mądrości, Uzdrowiciel, Wybawca, Przewodnik duchowy, Oświecony, współczujący Przyjaciel ubogich, dobry Samarytanin, Dobry Pasterz, Posłuszny" (Jan Paweł II, Ecclesia in Asia 20). Cenną sugestią jest też wizja Jezusa Chrystusa jako „wcielonej Mądrości Boga, którego łaska doprowadza do stanu dojrzałości 'ziarna’ Bożej Mądrości już obecne w życiu, w religiach i u ludów Azji”, a także jako Zbawcy nadającego sens życiu wszystkich cierpiących (Jan Paweł II, Ecclesia in Asia 20).

Powyższe dokumenty wskazują na doniosłą rolę, jaką - zdaniem Jana Pawła II - odgrywał dialog międzyreligijny. Papież ten rozwinął i pogłębił ideę wykształconą na Soborze Watykańskim II, a poprzez liczne pielgrzymki i spotkania z wyznawcami innych religii wykroczył poza wymiar teoretyczny i dał przykład praktycznego zaangażowania i zbliżenia.

\section{Benedykt XVI: dialog powołaniem Kościoła}

Benedykt XVI w czasie swego pontyfikatu podążał drogą wytyczoną przez Jana Pawła II. Idąc śladem swojego poprzednika, kontynuował także inicjatywy na rzecz dialogu międzyreligijnego ${ }^{10}$. Należą do nich liczne spotkania

${ }^{10}$ Niektórzy komentatorzy podkreślają różnice w podejściu Jana Pawła II i Benedykta XVI do dialogu z religiami niechrześcijańskimi. Jako argument wskazuje się m.in. zmianę formuły spotkania w Asyżu w 2011 r. (zrezygnowano ze wspólnej modlitwy). Jednak w zasadniczej treści kierunek pontyfikatu Benedykta XVI nie odbiega od drogi, którą podążał Jan Paweł II. Jak pisze Eugeniusz Sakowicz, „Pontyfikat trwał zbyt krótko, by wydawać obiektywne i udokumentowane oceny [...]. Obecnie widać bardzo wyraźnie, iż wizja jednego i drugiego papieża jest [...] komplementarna" (Sakowicz, Kontynuacja... 227). 
z przedstawicielami religii niechrześcijańskich w Watykanie i podczas zagranicznych pielgrzymek ${ }^{11}$, jak również urzeczywistnienie idei Dnia Modlitwy o Pokój w Asyżu. W kontekście niniejszych rozważań warte uwagi są dwie posynodalne adhortacje Benedykta XVI: Africae munus i Ecclesia in Medio Oriente. Pierwsza z nich to podsumowanie II Zgromadzenia Specjalnego dla Afryki Synodu Biskupów. Odbywało się ono w październiku 2009 r., stanowiąc kontynuację Zgromadzenia Synodu Biskupów Afryki z 1994 r. Adhortacja Africae munus ${ }^{12}$ podejmuje bieżące problemy, trudności i nadzieje Kościoła na kontynencie afrykańskim. Podobnie jak Jan Paweł II, również Benedykt XVI odnosi się do relacji Kościoła $\mathrm{z}$ islamem i z tradycyjnymi religiami afrykańskimi, zachęcając do szacunku dla obecnych w nich wartości oraz do podejmowania wspólnych działań na rzecz sprawiedliwości, pokoju i tolerancji ${ }^{13}$. Jednocześnie zwraca uwagę na zagrożenie, jakim jest praktykowanie czarów, wywodzące się z tradycyjnych religii. Problem ten dotyczy wielu katolików w Afryce i przybiera obecnie na sile ${ }^{14}$. Według Benedykta XVI Ko-

Dotyczy to także relacji z islamem. Środki przekazu, również te o charakterze katolickim, największą uwagę skupiły na wykładzie Benedykta XVI w Ratyzbonie, który wywołał kryzys w relacjach Kościoła ze wspólnotą muzułmańską. Jednak dalsze kroki papieża świadczą o pragnieniu dialogu. Relacje Benedykta XVI z islamem opracowała Agata Skowron-Nalborczyk. Określając wystąpienie w Ratyzbonie jako „trudne początki”, przedstawiła następnie pozytywny rozwój wzajemnych relacji poprzez pielgrzymki do Turcji, Jordanii i Izraela oraz inicjatywę strony muzułmańskiej, jaką był List 138 uczonych muzułmańskich do przywódców chrześcijaństwa (Skowron-Nalborczyk, 68-75).

${ }_{11}$ Szczególnie znaczące spotkania to: wizyta papieża w Błękitnym Meczecie w Stambule (30 listopada 2006) oraz pielgrzymka do Jerozolimy, podczas której Benedykt XVI modlił się pod Ścianą Płaczu i odwiedził meczet Al-Aksa (12 maja 2009).

${ }^{12}$ Podtytuł: 'Wy jesteście sola dla ziemi. [...] Wy jesteście świattem świata'(Mt 5,1.14).

13 „Sobór Watykański II uściśla, że Kościół 'zachęca [...] swoje dzieci, aby dając świadectwo wiary i życia chrześcijańskiego, z roztropnością i miłością przez wzajemne rozmowy i współpracę $\mathrm{z}$ wyznawcami innych religii poznawały, zachowywały i rozwijały te dobra duchowe i moralne, jak również te wartości społeczno-kulturalne, które się w nich znajdują'. [...] Zachęcam Kościół, aby we wszystkich sytuacjach 'spoglądał z szacunkiem również na muzułmanów, czcicieli jedynego Boga, żyjącego i samoistnego, miłosiernego i wszechmocnego Stworzyciela nieba i ziemi, Tego, który przemówił do ludzi'. Jeśli my wszyscy, wierzący w Boga, pragniemy służyć pojednaniu, sprawiedliwości i pokojowi, winniśmy działać razem, aby usuwać wszelkie formy dyskryminacji, nietolerancji i fundamentalizmu wyznaniowego" (Benedykt XVI, Africae... 92).

14 „Opierając się na religiach tradycyjnych czary przybierają obecnie na sile. Lęki odradzają się i tworzą więzy paraliżującego zniewolenia. Troski związane ze zdrowiem, dobrobytem, dziećmi, klimatem, ochroną przed złymi duchami, prowadzą od czasu do czasu do uciekania się do praktyk tradycyjnych religii afrykańskich, niezgodnych z nauczaniem chrześcijańskim. [...] Należy ukazać głębokie znaczenie tych praktyk czarnoksięstwa, rozeznając wyzwania teologiczne, społeczne i duszpasterskie, jakie niesie z sobą ta plaga” (Benedykt XVI, Africae... 93). Problem czarów stosowanych w kulturach afrykańskich podejmuje Eugeniusz Sakowicz: „Właściwy dla rodzimych afrykańskich religii permanentny stan lęku przed czarami i ich konsekwencjami wciąż trwa w życiu społecznym. Spotkać można nawet duchownych katolickich, którzy nie wyzwolili się z tego egzystencjalnego strachu i którzy praktykują tradycyjne obrzędy neutralizacji złych mocy. W strukturach społecznych miejsce wyjątkowe wciąż zajmują czarownicy, znachorzy, zaklinacze deszczu. Życie 
ściół powinien - poprzez katechezę i pogłębioną inkulturację - przeciwdziałać tym zjawiskom.

W adhortacji Ecclesia in Medio Oriente papież zwraca się do Kościoła Bliskiego Wschodu. Region ten to ojczyzna trzech religii monoteistycznych: judaizmu, chrześcijaństwa i islamu, wywodzących się ze wspólnego źródła wiary Abrahama. Historia oraz współczesna sytuacja Bliskiego Wschodu potwierdzają, że istotnym czynnikiem jest dialog międzyreligijny, stanowiący decydujący warunek pokoju i przetrwania Kościoła, którego istnienie w tym regionie jest szczególnie zagrożone. W październiku 2010 r. miały miejsce obrady Specjalnego Zgromadzenia Synodu Biskupów, poświęcone Bliskiemu Wschodowi. Skupiały się one wokół tematu: „Kościół katolicki na Bliskim Wschodzie: komunia i świadectwo. 'Jeden duch i jedno serce ożywiały wszystkich, którzy uwierzyli' (Dz 4,32)”. Posynodalna adhortacja ogłoszona została dwa lata później, 14 września 2012 r., podczas pielgrzymki Benedykta XVI do Libanu. Dokument odnosi się w 10 paragrafach do problematyki dialogu międzyreligijnego, bazującego na ,więzach duchowych i historycznych, łączących chrześcijan z żydami i muzułmanami”. Papież zaznacza, że tym, co dyktuje konieczność podejmowania dialogu, nie są względy natury pragmatycznej, politycznej czy społecznej, ale podstawy teologiczne, pochodzące z samego sedna wiary chrześcijańskiej: „Natura i powszechne powołanie Kościoła wymagają, aby prowadził on dialog z wyznawcami innych religii” (Benedykt XVI, Ecclesia... 19).

Papież przypomina o więzach istniejących między chrześcijanami a żydami, osadzonymi we wspólnym dziedzictwie duchowym, którym jest wiara w jedynego Boga oraz Biblia. O żydowskich korzeniach chrześcijaństwa przypomina także ludzka tożsamość Jezusa Chrystusa i Jego Matka - Maryja. „Te ścisłe więzy są wyjątkowym dobrem, z którego wszyscy chrześcijanie są dumni i które zawdzięczają Narodowi Wybranemu" (Benedykt XVI, Ecclesia... 20). Benedykt XVI zapewnia również o szacunku Kościoła dla muzułmanów, którzy oddają Bogu cześć przez modlitwę, jałmużnę i post, czczą Jezusa jako proroka, choć nie uznają Jego boskości, oddają też cześć Jego dziewiczej Matce - Maryi. Ojciec Święty z żalem przyznaje, że różnice doktrynalne między islamem a chrześcijaństwem wielokrotnie służyły jako pretekst do uzasadniania nietolerancji, dyskryminacji, a nawet prześladowania (Benedykt XVI, Ecclesia... 23). Wskazuje jednak na praktykowanie dialogu, które od wieków ma miejsce pomiędzy bliskowschodnimi chrześcijanami a muzułmanami: jest to dialog życia codziennego. Papież zwraca też uwagę na nowszy dialog żydowsko-chrześcijański oraz od dawna istniejący w tym regionie dialog inte- 
lektualistów i teologów żydowskich, chrześcijańskich i muzułmańskich. Dlatego stwierdza: ,Jest to laboratorium różnych spotkań i badań, które należy propagować" (Benedykt XVI, Ecclesia... 28).

Benedykt XVI apeluje do wszystkich „synów Abrahama”, mieszkających na Bliskim Wschodzie, o wzajemny szacunek, miłość i świadectwo życia w pokoju. Wskazuje też na konieczność uznania wspólnego wkładu żydów, chrześcijan i muzułmanów w kształtowanie bogatej kultury, specyficznej dla Bliskiego Wschodu (Benedykt XVI, Ecclesia... 24).

\section{Franciszek: dialog w prawdzie i miłości}

Trwający od 2013 r. pontyfikat Franciszka uwypukla nową perspektywę misyjną, w której misjonarzem staje się każdy wierzący, wezwany do dzielenia się Ewangelią w realiach swojego życia. Najpełniej wyraża to adhortacja Evangelii gaudium (z 24 listopada 2013), uznana za programowy tekst Franciszka. Mimo że podejmuje obszerny zakres zagadnień, koncentrują się one na temacie głoszenia Ewangelii ${ }^{15}$, a jej słowem kluczowym jest „nowa ewangelizacja". Adhortacja ma więc charakter misyjny w nowym znaczeniu; nie skupia się na misjach ad gentes, ale wskazuje różne obszary ewangelizacji: działalność duszpasterską, ożywianie wiary wśród ochrzczonych, którzy nie żyją zgodnie z wymogami chrztu świętego, oraz głoszenie Ewangelii ludziom nieznającym Chrystusa. „Na mocy otrzymanego Chrztu, każdy członek Ludu Bożego stał się uczniem misjonarzem” - stwierdza papież (Franciszek 120). Chrześcijanie są zatem zobowiązani do głoszenia Ewangelii wszystkim bez wyjątku, „nie jak ktoś, kto narzuca nowy obowiązek, ale jak ktoś, kto dzieli się radością" (Franciszek 14).

Franciszek jest papieżem dialogu. Postawa ta wyraża się także w stosunku do religii niechrześcijańskich. Adhortacja Evangelii gaudium poświęcona jest przeważnie dialogowi społecznemu, nazwanemu ,wkładem na rzecz pokoju”. Franciszek wyróżnia tutaj dialog między wiarą, rozumem i nauką (242-243), dialog ekumeniczny (244-246), relacje z judaizmem (247-249) oraz dialog międzyreligijny (250-254). Papież zapewnia w ten sposób wyjątkową pozycję religii żydowskiej, niebędącej dla Kościoła obcą rzeczywistością, ale „świętym korzeniem tożsamości chrześcijańskiej” (Franciszek 247). Ważną deklaracją jest również stwierdzenie, że „Bóg nadal działa w narodzie Starego Przymierza i sprawia, że rodzą się skarby mądrości wypływające z jego spotkania ze Słowem Bożym. Dlatego również Kościół się wzbogaca, gdy przyjmuje wartości judaizmu" (Franciszek 249).

\footnotetext{
${ }^{15}$ Wskazuje na to podtytuł adhortacji: O głoszeniu Ewangelii we współczesnym świecie.
} 
Odnosząc się do relacji z islamem, papież w pierwszej kolejności przypomina wypowiedź Soboru Watykańskiego II, że muzułmanie „czczą wraz z nami jedynego i miłosiernego Boga" (KK 16). Następnie wyraża uznanie dla religijnej gorliwości wyznawców islamu, którzy „są zdolni poświęcić codziennie czas na modlitwę i uczestniczyć wiernie w swoich obrzędach religijnych. Jednocześnie wielu z nich jest głęboko przekonanych, że ich życie w całości należy do Boga i jest dla Niego. Uznają także konieczność odpowiadania Bogu przez etyczne zaangażowanie i miłosierdzie wobec najuboższych” (Franciszek 252). Franciszek wzywa do unikania „wrogich uogólnień”, przypisujących wszystkim muzułmanom odpowiedzialność za akty przemocy, i wyraża przekonanie, że ,prawdziwy islam i poprawna interpretacja Koranu sprzeciwiają się wszelkiej przemocy”. Stwierdzając, że chrześcijanie z otwartością powinni przyjmować islamskich migrantów, prosi jednocześnie kraje muzułmańskie o zapewnienie wolności wyznania mieszkającym tam chrześcijanom (Franciszek 253).

Franciszek wskazuje cechy, które powinny charakteryzować dialog międzyreligijny: jest to ,postawa otwarcia w prawdzie i miłości” i jednocześnie odrzucenie „pojednawczego synkretyzmu” oraz „otwarcia dyplomatycznego, które zgadza się ze wszystkim, by uniknąć problemów". W imię dialogu nie można rezygnować z własnej tożsamości, ponieważ prowadzi to do „oszukania drugiego człowieka i odmówienia mu dobra, które otrzymaliśmy jako dar, by się nim hojnie podzielić" (Franciszek 251). Postawa otwartości i dialogu jest wyrazem miłości do prawdy oraz wyrazem zaangażowania na rzecz pokoju, dlatego stanowi powinność zarówno chrześcijan, jak i innych wspólnot religijnych (Franciszek 250). Dialog międzyreligijny pozwala też dostrzec w innych religiach działanie Ducha Świętego, który budzi w nich „formy praktycznej mądrości, pomagające znosić trudy życia i żyć w większym pokoju i harmonii”. Dlatego - pisze papież - „także i my, chrześcijanie, możemy odnieść korzyść z takiego utrwalonego przez wieki bogactwa, które może pomóc nam żyć lepiej naszymi szczególnymi przekonaniami” (Franciszek 250). Sposób, w jaki Franciszek pojmuje dialog międzyreligijny, jest zatem wynikiem podążania drogą Soboru i papieży-poprzedników. Obecny papież, podobnie jak oni, włącza dialog w zakres misji Kościoła posłanego do całego świata $\mathrm{z}$ orędziem pokoju.

Dyskredytowanie wartości obecnych w religiach niechrześcijańskich nie może być drogą głoszenia Ewangelii. Działalność misjonarska, bazująca na krytyce zastanej religii, prowadzi do wątpliwych rezultatów. Kościół pod- 
kreśla obecność elementów prawdy w religiach niechrześcijańskich, głosząc jednocześnie potrzebę ich dopełnienia w bezpośrednim spotkaniu z Jezusem Chrystusem. Zadaniem uczniów Jezusa Chrystusa jest prowadzenie do Niego wszystkich ludzi, On bowiem jest wypełnieniem wszelkich pragnień, oczekiwań, aspiracji i tęsknot wyrażających się poprzez religijne praktyki, wierzenia czy mity. Kościól, głosząc Ewangelię wśród narodów, ma ukazywać, że przyjęcie Chrystusa nie oznacza odrzucenia bogactwa rodzimych tradycji i wartości, ale ich uświęcenie i wypełnienie: „Jego Ewangelia niczego nie odbiera wolności człowieka, należnemu poszanowaniu kultur, ani temu, co dobre w każdej religii" - głosi Jan Paweł II (Jan Paweł II, Redemptoris missio 3). Sobór Watykański II wyraża przekonanie, że w spotkaniu z Ewangelią ,,jakikolwiek dobry posiew znajdujący się w sercach i umysłach ludzkich lub we własnych obrządkach i kulturach narodów, nie tylko nie ginie, lecz doznaje uleczenia, wyniesienia na wyższy poziom i pełnego udoskonalenia na chwałę Bożą" (DM 9). Już w starożytności chrześcijańskiej ukształtowane zostało pojęcie preparatio evangelica, pozwalające postrzegać elementy występujące w innych kulturach i religiach jako przygotowanie ludzkich serc i umysłów do przyjęcia Ewangelii. Dialog międzyreligijny pozwala odkryć i nazwać po imieniu te elementy, które już ojcowie Kościoła określali jako semina Verbi ziarna Słowa, zasiane w religiach niechrześcijańskich.

\author{
DIALOGUE OR MISSION? \\ DOCUMENTS OF THE CATHOLIC CHURCH \\ ON MISSION TOWARDS INTERRELIGIOUS DIALOGUE
}

\title{
Summary
}

The Second Vatican Council opened a new perspective for interreligious dialogue for the Church. Theological reflection, including non-Christian religions, pointed out the elements of truth and holiness present in them and confirmed their value as preparation for the Gospel. This positive image of religion does not conflict with missionary activity. The conciliar and post-conciliar documents of the Church emphasize the constant validity of the missionary mission of Christians and indicate dialogue as one of the forms of mission. Significantly, the topic of interreligious dialogue is primarily addressed in missionary documents that recognize it as an integral part of the preaching of the Gospel. The Council decree Ad gentes divinitus, the exhortation of Paul VI Evangelii nuntiandi, the encyclical of John Paul II Redemptoris missio are just some of the Church's many missionary documents that develop the concept of interreligious dialogue. 
Keywords: interreligious dialogue; missionary documents; missions ad gentes; Second Vatican Council; Church towards non-Christian religions

Słowa kluczowe: dialog międzyreligijny; dokumenty misyjne; misje ad gentes; Sobór Watykański II; Kościół wobec religii niechrześcijańskich

\section{WYKAZ SKRÓTÓW}

DM - Dekret o działalności misyjnej Kościoła „Ad gentes divinitus”

DRN - Deklaracja o stosunku Kościoła do religii niechrześcijańskich „Nostra aetate”

KK - Konstytucja dogmatyczna o Kościele „Lumen gentium”

\section{BIBLIOGRAFIA}

Benedykt XV. List apostolski „Maximum illud” (30 XI 1919). Nauczycielski Urząd Kościoła a religie. Red. Ireneusz Ledwoń. Lublin: Wydawnictwo KUL, 2015. 161-165.

Benedykt XVI. Adhortacja apostolska „Africae munus” (19 XI 2011). Nauczycielski Urząd Kościoła a religie. Red. Ireneusz Ledwoń. Lublin: Wydawnictwo KUL, 2015. 639-644.

Benedykt XVI. Adhortacja apostolska „Ecclesia in Medio Oriente” (14 IX 2012). Nauczycielski Urzą Kościoła a religie. Red. Ireneusz Ledwoń. Lublin: Wydawnictwo KUL, 2015. 645-648.

Chrześcijaństwo a religie. Dokument Międzynarodowej Komisji Teologicznej. Tekst - komentarze - studia. Red. Ireneusz Ledwoń, Kazimierz Pek. Warszawa: Wydawnictwo Księży Marianów, 1999.

Deklaracja o stosunku Kościoła do religii niechrześcijańskich „Nostra aetate” (28 X 1965). Sobór Watykański II. Konstytucje, dekrety, deklaracje. Poznań: Pallottinum, 1986. 334-338.

Dekret o działalności misyjnej Kościoła „Ad gentes divinitus” (18 XI 1965). Sobór Watykański II. Konstytucje, dekrety, deklaracje. Poznań: Pallottinum, 1986. 436-474.

Franciszek. Adhortacja apostolska „Evangelii gaudium” (24 XI 2013). Kraków: Wydawnictwo M, 2013.

Grzegorz XVI. Encyklika „Probe nostis” (15 VIII 1840). Nauczycielski Urząd Kościoła a religie. Red. Ireneusz Ledwoń. Lublin: Wydawnictwo KUL, 2015. 122-123.

Islam w dokumentach Kościoła i nauczaniu Jana Pawła II (1965-1996). Red. Eugeniusz Sakowicz. Warszawa: Wydawnictwo UKSW, 1997.

Jan Paweł II. Encyklika „Redemptoris missio” (7 XII 1990). Wrocław: Wydawnictwo Wrocławskiej Księgarni Archidiecezjalnej Tum, 1995.

Jan Paweł II. Posynodalna adhortacja apostolska „Ecclesia in Africa” (14 IX 1995). Dostęp 30 sierpnia 2018. <https://w2.vatican.va/content/john-paul-ii/p1/apost_exhortations/documents/hf_jp-ii_exh_14091995_ecclesia-in-africa.html >

Jan Paweł II. Posynodalna adhortacja apostolska „Ecclesia in America” (22 I 1999). Ecclesia in America. Wybrane problemy Kościoła w Ameryce Poludniowej w świetle posynodalnej adhortacji Jana Pawła II. Red. Jarosław Różański. Warszawa: Missio-Polonia, 2006. 243-338.

Jan Paweł II. Posynodalna adhortacja apostolska „Ecclesia in Asia” (6 XI 1999). Ecclesia in Asia. Wybrane problemy Kościoła w Azji w świetle posynodalnej adhortacji Jana Pawła II. Red. Jarosław Różański. Warszawa: Missio-Polonia, 2004. 9-96. 
Jan Paweł II. Posynodalna adhortacja apostolska „Ecclesia in Oceania” (22 XI 2001). Ecclesia in Oceania. Wybrane problemy Kościoła w Oceanii w świetle posynodalnej adhortacji Jana Pawta II. Red. Jarosław Różański. Warszawa: Missio-Polonia, 2006. 13-92.

Kamykowski, Łukasz. Dokument „Chrześcijaństwo a religie” a dialog międzyreligijny - wzajemne relacje. Chrześcijaństwo a religie. Dokument Międzynarodowej Komisji Teologicznej. Red. Ireneusz Ledwoń, Kazimierz Pek. Warszawa: Wydawnictwo Księży Marianów, 1999. 101-122.

Kluj, Wojciech. „Misje”. Jan Pawet II. Encyklopedia dialogu i ekumenizmu. Red. Eugeniusz Sakowicz. Radom: Polskie Wydawnictwo Encyklopedyczne, 2006. 335-353.

Kluj, Wojciech. Teologiczne podstawy misji wedtug Jana Pawła II, Warszawa: Instytut Papieża Jana Pawła II, 2008.

Konstytucja dogmatyczna o Kościele „Lumen gentium” (21 XI 1964). Sobór Watykański II, Konstytucje, dekrety, deklaracje, Poznań: Pallotinum, 1986. 105-170.

Leon XIII. Encyklika „Catholicae Ecclesiae” (20 XI 1890). Nauczycielski Urząd Kościoła a religie. Red. Ireneusz Ledwoń. Lublin: Wydawnictwo KUL, 2015. 143-144.

Leon XIII. Encyklika „Sancta Dei civitas” (3 XII 1880). Nauczycielski Urząd Kościoła a religie. Red. Ireneusz Ledwoń. Lublin: Wydawnictwo KUL, 2015. 140.

Masson, Joseph. Dekret o działalności misyjnej Kościoła. Komentarz. Pieniężno, 1968.

Paweł VI. Adhortacja apostolska „Evangelii nuntiandi” (8 XII 1975). Wrocław: Wydawnictwo Wrocławskiej Księgarni Archidiecezjalnej Tum, 2001.

Paweł VI. Encyklika „Ecclesiam suam” (6 VIII 1964). Wrocław: Wydawnictwo Wrocławskiej Księgarni Archidiecezjalnej Tum, 2006.

Paweł VI. „Przemówienie do członków wyższych rad generalnych Papieskich Dzieł Misyjnych i Unii Misyjnej Kleru” (14 V 1965). Nauczycielski Urząd Kościoła a religie. Red. Ireneusz Ledwoń. Lublin: Wydawnictwo KUL, 2015. 242.

Piotrowski, Jan. „Historia powstania i główne idee teologiczne Ecclesia in Asia.” Ecclesia in Asia. Wybrane problemy Kościoła w Azji w świetle posynodalnej adhortacji Jana Pawła II. Red. Jarosław Różański. Warszawa: Missio-Polonia, 2004. 97-108.

Piotrowski, Jan. „Prawdziwy Kościół żyje w Afryce. Adhortacja posynodalna Jana Pawła II Ecclesia in Africa w świetle nauczania soborowego i posoborowego." Ewangelia między tradycja a współczesnościa afrykańską. Red. Jarosław Różański. Warszawa: Missio-Polonia, 2003. $117-$ $-128$.

Pius IX. Encyklika „Quanto conficiamur moerore” (10 X 1863). Nauczycielski Urząd Kościoła a religie. Red. Ireneusz Ledwoń. Lublin: Wydawnictwo KUL, 2015. 124-125.

„Postawa Kościoła wobec wyznawców innych religii (1984).” Sekretariat dla Niechrześcijan. Nauczycielski Urząd Kościoła a religie. Red. Ireneusz Ledwoń. Lublin: Wydawnictwo KUL, 2015. 686-698.

Sakowicz, Eugeniusz. „Dialog Kościoła katolickiego z tradycyjnymi religiami Oceanii.” Ecclesia in Oceania. Wybrane problemy Kościoła w Oceanii w świetle posynodalnej adhortacji Jana Pawta II. Red. Jarosław Różański. Warszawa: Missio-Polonia, 2006. 107-127.

Sakowicz, Eugeniusz. „Dialog międzyreligijny w Afryce w służbie pojednania, sprawiedliwości i pokoju." Ecclesia in Africa. Pojednanie, sprawiedliwość i pokój-wyzwania dla Kościoła w Afryce na początku XXI w. Red. Jarosław Różański. Warszawa: Missio-Polonia, 2006. 133-145.

Sakowicz, Eugeniusz. „Dialog międzyreligijny.” Jan Pawet II. Encyklopedia dialogu i ekumenizmu. Red. Eugeniusz Sakowicz. Radom: Polskie Wydawnictwo Encyklopedyczne, 2006. 129-161.

Sakowicz, Eugeniusz. „Kontynuacja czy innowacja? Benedykt XVI wobec dialogu międzyreligijnego." Chrześcijaństwo a kultura. Red. Roman Bartnicki, Witold Kawecki. Warszawa: Wydawnictwo UKSW, 2006, s. 211-229.

Skowron-Nalborczyk, Agata. „Kontynuacja czy zerwanie? Benedykt XVI wobec islamu.” Więź 4 (2010): 68-75.

„Sugestie do dialogu między religiami (1967).” Sekretariat dla Niechrześcijan. Nauczycielski Urząd Kościoła a religie. Red. Ireneusz Ledwoń. Lublin: Wydawnictwo KUL, 2015. 655-686. 
Sobór we Florencji. Bulla „Cantate Domino” (4 II 1442). Nauczycielski Urząd Kościoła a religie. Red. Ireneusz Ledwoń. Lublin: Wydawnictwo KUL, 2015. 48-49.

Szuppe, Paweł. „Jezus Chrystus w tradycyjnych religiach afrykańskich.” Ewangelia między tradycja a wspótczesnością afrykańską, Warszawa: Missio-Polonia, 2003. 149-157.

Zięba, Maciej. Wprowadzenie. Encykliki Ojca Świętego Jana Pawła II. T. 1. Kraków: Wydawnictwo św. Stanisława BM, 1996. V-XXVIII.

Żydzi i judaizm w nauczaniu Jana Pawła II (1978-2005). Red. Waldemar Chrostowski. Warszawa: Wydawnictwo Archidiecezji Warszawskiej, 2005.

Magdalena RzYM, doktor nauk teologicznych z zakresu misjologii na Wydziale Teologicznym UKSW w Warszawie (2019). 